\title{
Evaluation of seismic and petrophysical parameters for hydrocarbon prospecting of G-field, Niger Delta, Nigeria
}

\author{
Anthony Aduojo Ameloko ${ }^{1} \cdot$ George Chiemeziem Uhegbu' ${ }^{1}$ Eniola Bolujo ${ }^{1}$
}

Received: 15 February 2019 / Accepted: 16 July 2019 / Published online: 23 July 2019

(c) The Author(s) 2019

\begin{abstract}
Adequate analyses of seismic and petrophysical data help to minimize drilling risk and maximize well and reservoir productivity. Reservoir characterization was carried out to provide information and improve understanding of the geological and petrophysical parameters, and hence improve decision making regarding the development of the field under study. Wireline logs obtained from three wells as well as a 3D Seismic data coverage of G-field in the Niger Delta were evaluated using the petrel software. Suites of gamma and deep resistivity logs aided the delineation and correlation of the sandstone unit, while the top was tied to the seismic data using synthetic seismogram to determine seismic characters. Well correlation enabled the delineation of reservoir sand across the wells. The quality of the reservoir was determined from petrophysical averages, in which the reservoir has an average thickness of $72 \mathrm{~m}$, average porosity of 0.31 , average net to gross of 0.75 , average $V$-shale of 0.25 , and average water saturation of 0.19 , respectively. Listric normal faults were mapped across the field. The models reveal lateral and horizontal variations in reservoir properties which capture subsurface heterogeneity and anisotropy across the reservoir sand, and also possible sweet-spot zones were identified. These are diagnostic of areas for future exploitation and recovery of hydrocarbon. Seismic attributes analysis was done to predict variation in lithofacies across the sandstone body.
\end{abstract}

Keywords Reservoir $\cdot$ Seismic $\cdot$ Logs $\cdot$ Porosity $\cdot$ Faults

\section{Introduction}

Many dry holes have been drilled in the Niger Delta as a result of inaccurate analysis of the integrity of the numerous fault-dependent closures and stratigraphic setting associated with the basin. The Niger Delta like many deltaic areas is extremely difficult to define due to the heterogeneous nature of the various sedimentary lithofacies units associated with it. This complex physical property of the basin has made it extremely difficult to define formations and their interfaces. And so integration of 3D seismic and well data for structural interpretation and reservoir characterization is a continuous process of providing an improved understanding of the geological and petrophysical controls of fluid flows in the reservoir. It encompasses all methods and techniques that can lead to a well-improved understanding and a much better handling of the reservoir. Reservoir characterization

Anthony Aduojo Ameloko

tonyameloko@yahoo.com

1 Department of Petroleum Engineering, Covenant University, Ota, Nigeria is defined as a systematic means of quantitatively determining and assigning reservoir properties, establishing geologic information and uncertainty in spatial variability (Lake and Carroll 1986). Subsurface configurations must be well understood in order to be able to efficiently delineate the structures that are favorable for the accumulation of hydrocarbon; and several geologic parameters are important accumulation, gas and oil in large quantities, to form a pool sufficient enough for production. These parameters include good source rock (an organic-rich) to produce the oil or gas, a reservoir rock with sufficient porosity to accommodate the hydrocarbon, and good structural framework to prevent the oil and gas from leaking away (Coffen 1984). The importance of data integration is usually in improvement in the accuracy of mapping complicated structural plays (Adejobi and Olayinka 1997). When 3D seismic data are interpreted and made clear with modern computer workstations and software for interpretation, structural mapping can be done swiftly and accurately. However, it is not enough just to map the top of the reservoir (as was the case in two dimensions). To understand how structures were formed and when, it is usually necessary to map a range of marker horizons above

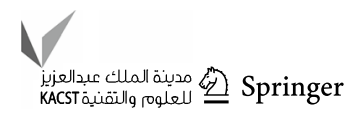


and below the target. This study therefore was aimed at integrating well and seismic data obtained from the field under study, to effectively characterize subsurface sandstone reservoir and evaluate its hydrocarbon potentials.

\section{Location and geology of the study area}

The G-field is located in the Niger Delta basin in Nigeria (Fig. 2). The basin is characteristically a clastic wedgeshaped structure located along a failed arm of a triple junction framework (aulacogen) initially developed as a result of the separation of the South American and African plates during the late Jurassic time (Burke 1972; Whiteman 1982). The two arms are associated with the southwestern and southeastern coast of Nigeria and Cameroon formed into the passive continental margin of West Africa, while the third failed arm formed the Benue Trough. The sub-areal bit of the Niger Delta covers around $75,000 \mathrm{~km}^{2}$ territory inside the Gulf of Guinea and extending more than $300 \mathrm{~km}$ from summit to mouth. In spite of the way that the progressed Niger Delta shaped in the early tertiary, residue began to accumulate in this area in the midst of Mesozoic breaking associated with the partition of the African and South American landmasses (Doust and Omatsola 1990; Evamy et al. 1978; Weber and Daukoru 1975). Like many deltaic areas, the Niger Delta is complex and it is difficult to determine a satisfactory stratigraphic signature. The improper alignment of a small number of lithofacies makes it difficult to establish units and boundaries of sufficient integrity to constitute separate formations in a formal sense. However, three formation names are in widespread use corresponding to the portions of the tripartite sequence previously described (Avbovbo 1978; Short and Stauble 1967). In the Nigerian oil industry, these three are usually referred to in the lithofacies terms. The Niger Delta basin is divided into three main formations: Akata, Agbada and the Benin Formations. The oldest of them is the Akata Formation, which is made up of thick sequences of shale and it is regarded as the source rock for hydrocarbon formation. The origin of this important unit of the basin is related to the transportation of terrestrial organic matter and clays to deep offshore waters at the beginning of Paleocene (Tuttle et al. 1990). According to Doust and Omatsola (1990), the formation is estimated to be about $7000 \mathrm{~m}$ thick, and underlies the entire delta with high overpressure. The Agbada Formation directly overlies the Akata Formation and constitutes the main hydrocarbon reservoir of the entire Niger Delta. It is made up of sequences of sands and shales (paralic siliciclastics) with thickness of over $3700 \mathrm{~m}$; it is the transition zone and represents the deltaic portion of the Niger Delta sequence (Doust and Omatsola 1990; Tuttle et al. 1990). Overlying the Agbada Formation is the Benin. Benin Formation composes mainly of alluvial sands and characterized by thicknesses of about 2000 m (Avbovbo 1978) (Fig. 1).

\section{Materials and methods}

\section{Seismic and well log data analyses}

Well logs and seismic data were utilized in this study. The 3D seismic data covered a region of approximately $58.24 \mathrm{~km}^{2}$ on a scale of 1:250,000. Other datasets utilized in this research include: check shot data and composite geophysical well logs containing chiefly gamma ray, spontaneous potential, neutron, density, sonic and resistivity logs of three wells (copia A, copia B and copia C). The base map of the G-field showing the coverage of the seismic data as well as spatial locations of the three wells is shown in Fig. 2. As shown in the workflow chart in Fig. 3, the dataset available was first imported into the Petrel software for examination. Logs such as bulk density and P-sonic which were affected by noise and responses not related to geology were scrutinized for spikes and errors before log-based interpretation was done. Additionally, the logs were viewed on appropriate scales and normalized.

\section{Correlation of hydrocarbon-bearing sand bodies}

The hydrocarbon-bearing sand bodies were delineated and correlated over the wells making use of the composite well log suite of neutron-density, gamma ray and resistivity logs. The log shape (motif) of the sealing shales above the pay sandstone was used as means for litho-correlation of the sand bodies across the wells along a specific direction in the field. Also by means of flattening the wells at a specific depth, the identification of pay sand levels was less demanding, and furthermore, there were conceivable signs of the structural geometry within the field before shale tectonics and faulting above the sandstone level.

\section{Petrophysical properties estimation}

Petrophysical properties were predicted and approximated for the different identified hydrocarbon-wielding sand bodies of interest from the generated petrophysical logs. The rock parameters estimated include: total porosity, thickness, water saturation, effective porosity hydrocarbon saturation, volume of shale and net/gross.

\section{Well to seismic tie}

Seismic reflections take place at lithologic interfaces; therefore, it is important to identify the events (i.e., peak or trough) that represent the tops of the different sand bodies interpreted from the well log data. This process is known as 
Fig. 1 Stratigraphy of the Niger Delta basin (Doust and Omatsola 1990)

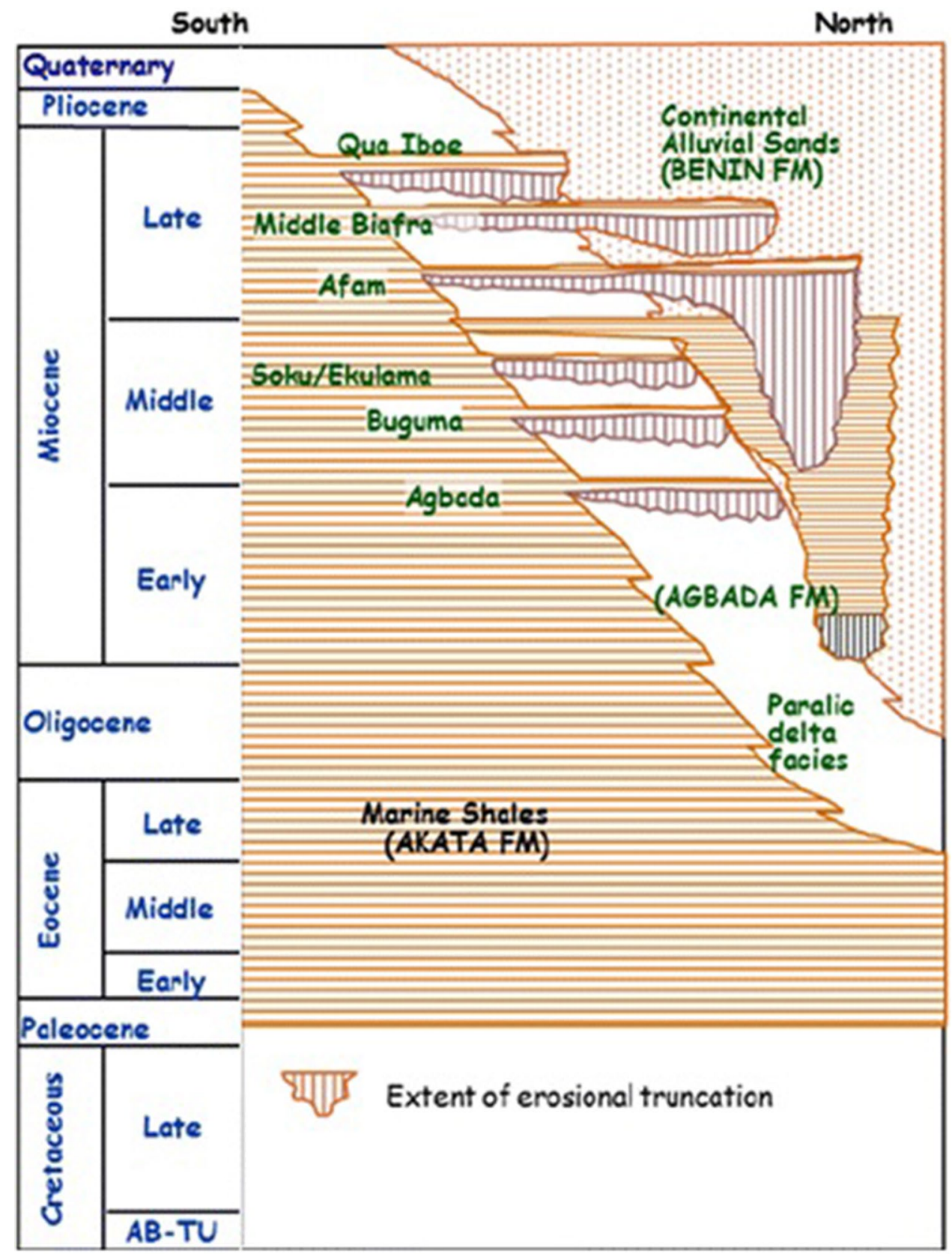

well to seismic tie and is usually carried out using an artificial or synthetic seismogram developed from the sonic and the density logs in the well. After the identification of events, the reservoir tops were posted on the seismic sections with the use of time-depth relationship data (i.e., checkshot data).

\section{Fault interpretation and horizon mapping}

The structural framework of a field is vital to comprehend the trapping mechanism and the relationship among faults and the fundamental anticlinal structures. Faults were interpreted or delineated from the inline sections moving at a step of 10. The criteria for the interpretation incorporate reflection discontinuities or sudden horizon termination and lateral change in seismic amplitude. The already identified event that corresponds to the top of hydrocarbon-bearing reservoir of concern was mapped across both inlines and crosslines as horizons moving likewise at a step of 10 . The fault framework that was built from fault interpretation gave rise to the horizon mapping and simple identification of downthrown and upthrown displacement of the horizon.

\section{Generation of time and depth structure maps}

The horizon mapping facilitated the generation of a time map (i.e., map depicting lines of equal time). The related

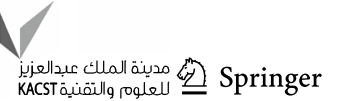




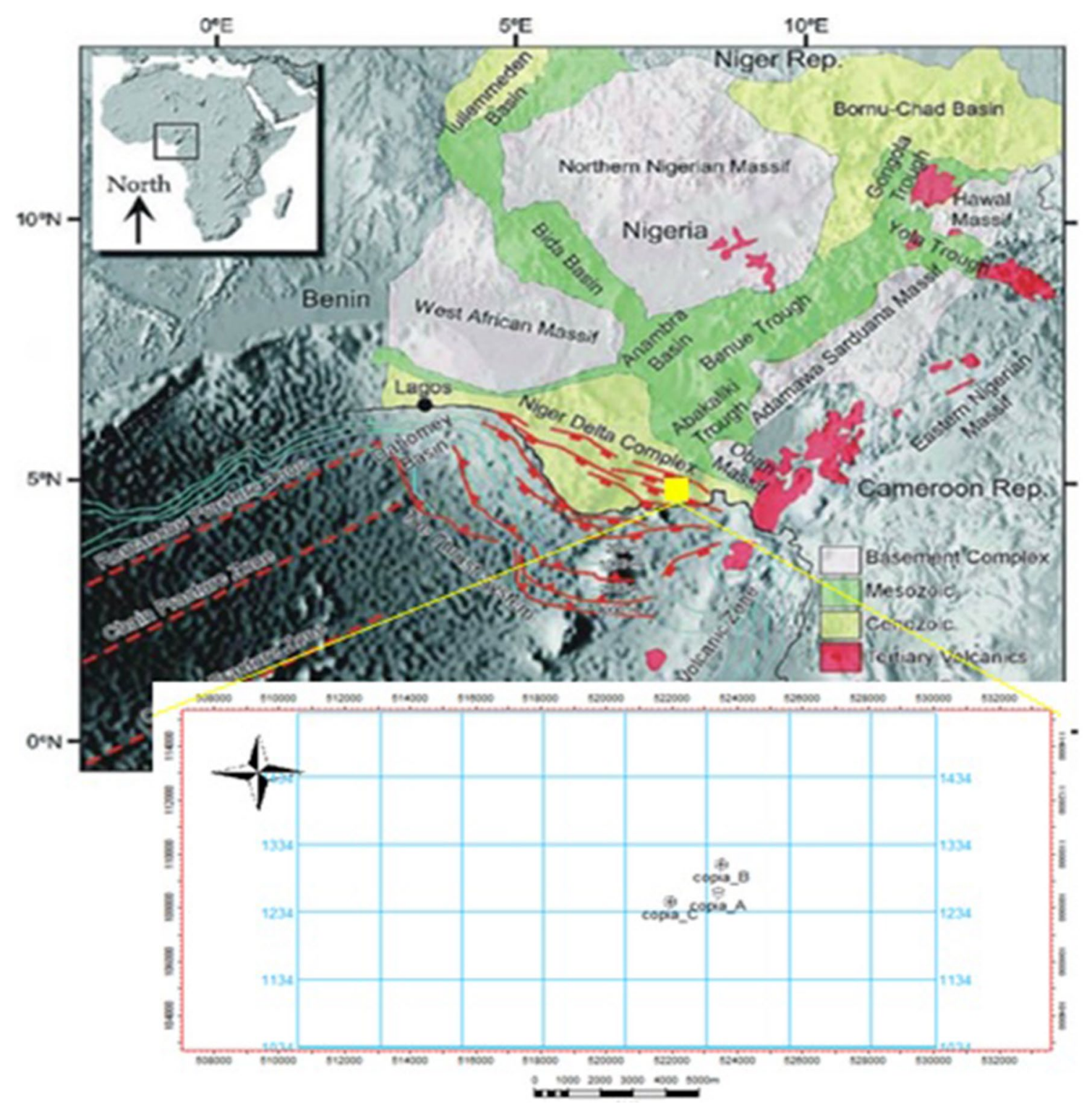

Fig. 2 Map of Niger Delta showing location of study area and the base map of the study area (Doust and Omatsola 1990)

depth map was created from a velocity model calibrated by the checkshot data. The appearance of faults on 2D known as fault polygons were superimposed on the depth map and time map to show their lateral extent and the direction of dip and also in identification of the structural mechanism that traps hydrocarbon at the pinpointed reservoir level (i.e., fault-dependent, fault-assisted structures, etc.).

\section{Results and discussion}

The well correlation shown in Fig. 4 enabled the delineation of the reservoir sand across the wells and the determination of spatial distribution of the reservoir fluids (Ameloko et al.
2016). Composite suites of gamma and deep resistivity logs were used to delineate one sandstone reservoir. The correlation was carried out to determine the lateral distribution of reservoir fluids and was guided from one well to the other using the log signatures or motifs of overlying sealing shale. This is because shales are laterally extensive and continuous. Differences in well tops across the wells at each reservoir levels indicate the presence of faulting (i.e., relative displacement) between wells and hence indicating that available wells are likely drilled within fault blocks. The correlation across the wells also laid the groundwork for calibrating the mapping of horizons and petrophysical analysis at different wells. Basic reservoir petrophysical parameters are important properties to effectively characterize interpreted 
Fig. 3 Workflow diagram showing various steps taken

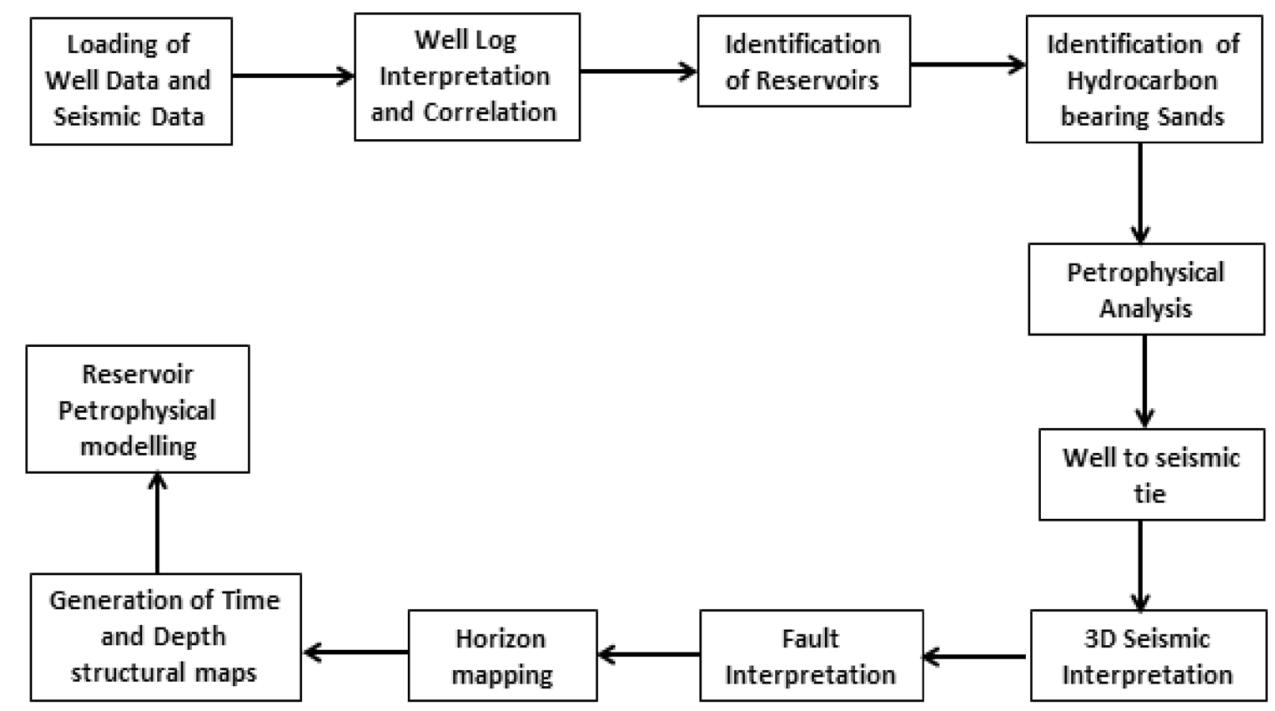

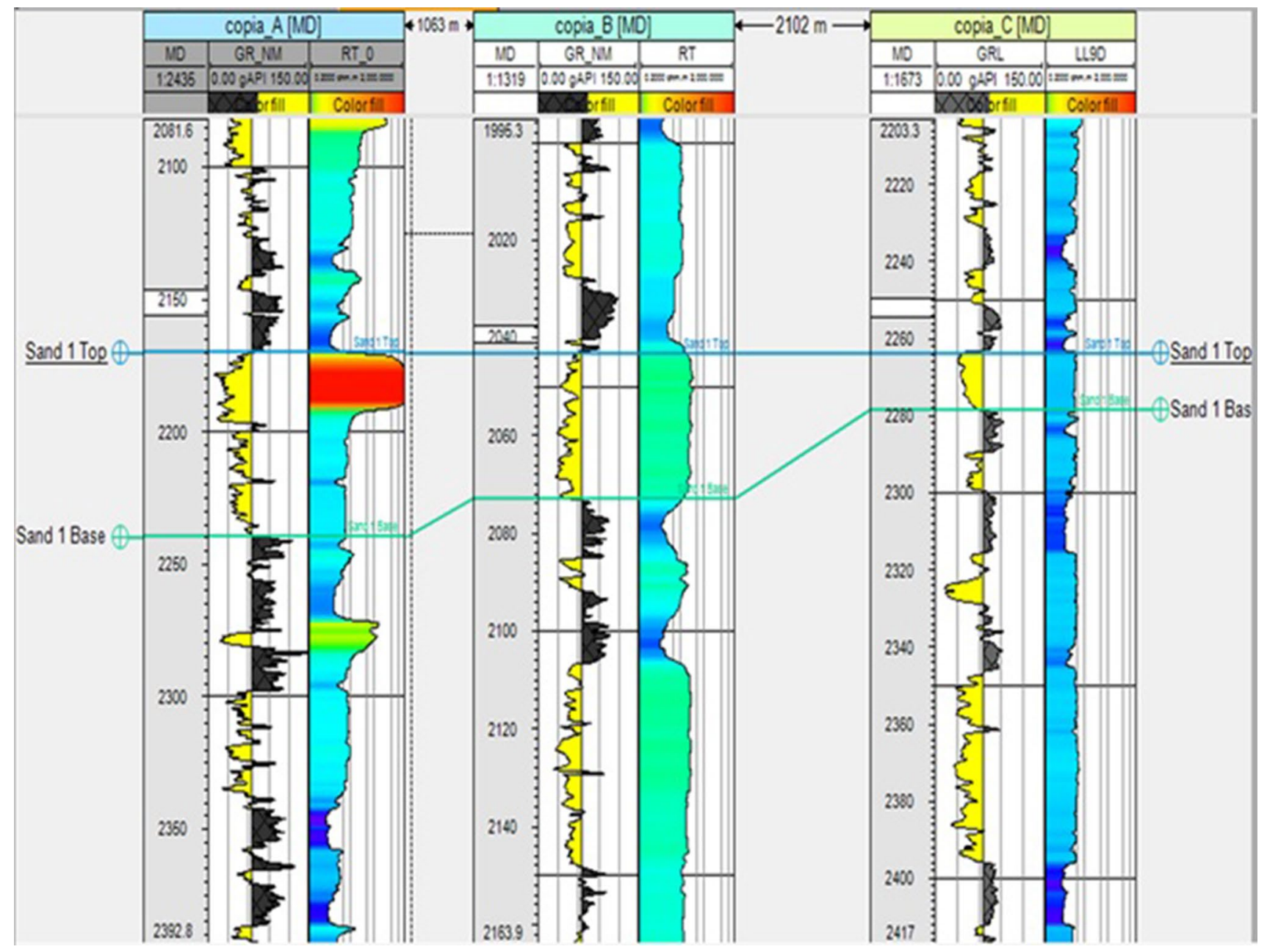

Fig. 4 Reservoir delineation and correlation across the field 
Table 1 Estimated averages of petrophysical parameter from wells

\begin{tabular}{llllll}
\hline Reservoir & $\begin{array}{l}\text { Thickness } \\
(\mathrm{m})\end{array}$ & $\begin{array}{l}\text { Average } \\
\text { porosity } \\
(\Phi)\end{array}$ & $\begin{array}{l}\text { Average } \\
\text { water } \\
\text { saturation } \\
\left(S_{\mathrm{w}}\right)\end{array}$ & $\begin{array}{l}\text { Average } \\
\text { volume of } \\
\text { shale }\left(V_{\mathrm{sh}}\right)\end{array}$ & $\begin{array}{l}\text { Average } \\
\text { net to } \\
\text { gross }\end{array}$ \\
\hline 1 & 71.78 & 0.31 & 0.19 & 0.25 & 0.75 \\
\hline
\end{tabular}

reservoirs zones because they give succinct information of pore spaces, clay and sand contents, reservoir gross thickness and the rock fluid saturation. Table 1 shows the average petrophysical parameters estimated from petrophysical logs for the sandstone reservoir from all available wells (Fig. 5). This includes thickness, porosity, net to gross, volume of shale, water and hydrocarbon saturation. The reservoir as delineated from the wells has an average thickness of $71.78 \mathrm{~m}$. The average neutron-density-derived porosity for the reservoir is $31 \%$, which suggests good average porosity. The porosity is satisfactory for a reservoir to be adjudged a producible reservoir (Ameloko and Owoseni 2015). The average water saturation (19\%) for the reservoir indicates that the reservoir is mainly hydrocarbon bearing (oil and gas). The low water saturation in the reservoir indicates $81 \%$ hydrocarbon saturation.

Well to seismic tie was carried out, and the horizon corresponding to the top of the reservoir was labeled horizon A (Fig. 6). This was achieved by mapping the continuous and strong seismic reflections which mark the top of the sandstone reservoir. It was characterized by a peak (i.e., positive reflection). This gives succinct information that

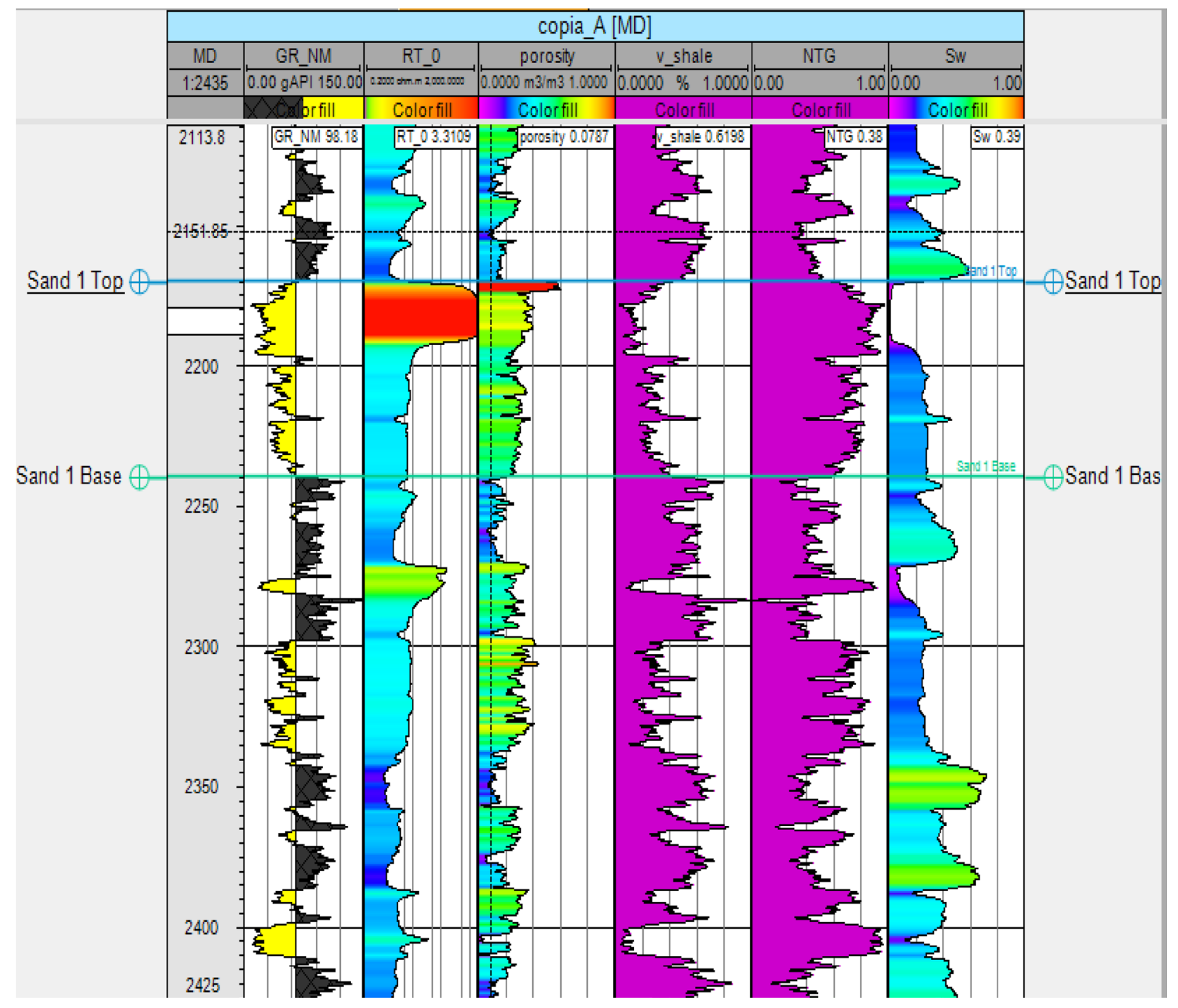

Fig. 5 Derived petrophysical logs from Copia A 
Fig. 6 Synthetic seismogram generated from well Copia $\mathrm{C}$

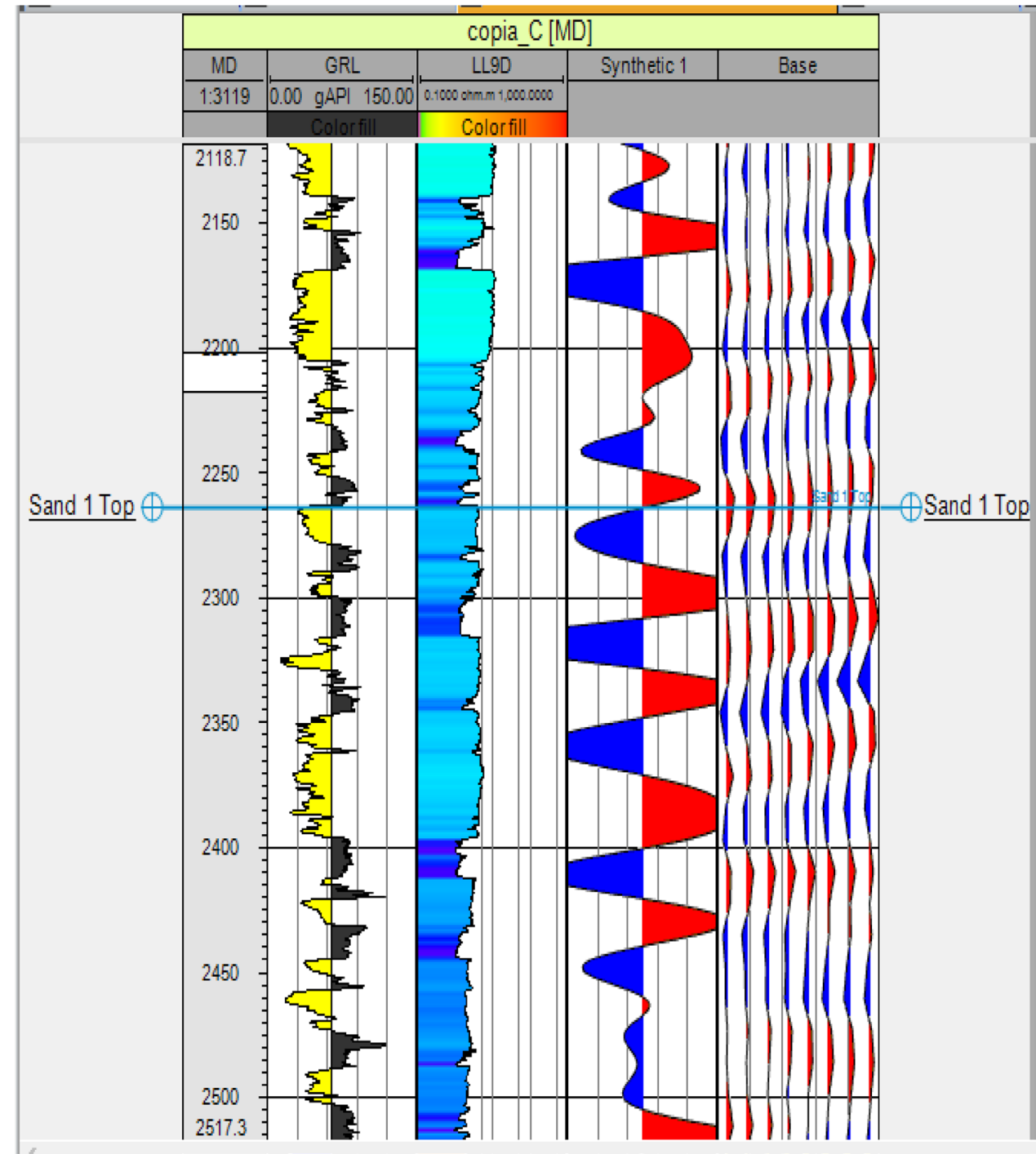

the reservoir sand has a higher elastic property (acoustic impedance) compared to the overlying shale facies. The horizon is also characterized by bright amplitudes at the seismic lines at the center of the field (Fig. 7). Acoustic impedance depends largely on P-velocity and density and hence depends on the underlying rock fabric, pore-fill and grain type and fluid type. The synthetic seismogram assisted in identifying the events that show the top of the sandstone reservoir. The validated sand intervals from the well log data were posted on the seismic data using the checkshot data. The generated synthetic seismogram from the well data also formed the basis of selecting the seismic character to track or interpret across the seismic lines (Ameloko et al. 2016).

The superimposed faults and gridded horizons are shown in Fig. 8. A total of four seismo-structural faults labeled A, $\mathrm{B}, \mathrm{C}$ and $\mathrm{D}$ were mapped across the field from the inline section that was analyzed. The faults were guided by an extracted time slice from a structural local azimuth attribute.
This aided the lateral mapping of faults trends and patterns across the field and also the creation of the $2 \mathrm{D}$ fault polygons (Fig. 9). Faults A, B, C all dip toward the east, while fault $\mathrm{D}$ dips in the opposite direction. Most of the faults within the Niger Delta extensional zone are formed due to mobile Akata shale diapirism and gravity slope instability (Doust and Omatsola 1990).

The gridded horizon was used to generate a time structural map of the reservoir top (Fig. 10), and a suitable velocity model constrained by the reservoir well top was used to generate the corresponding depth structural maps of the mapped reservoir top (Fig. 11). The similarity of the time and depth maps at the reservoir gives credence to the results of this study and consistency in the interpretation. The depth structure map of the reservoir indicates that the structural trapping system accumulating hydrocarbon is a fault-dependent anticlinal structure since the strike of most faults runs close to the crest of the closures. However, for 


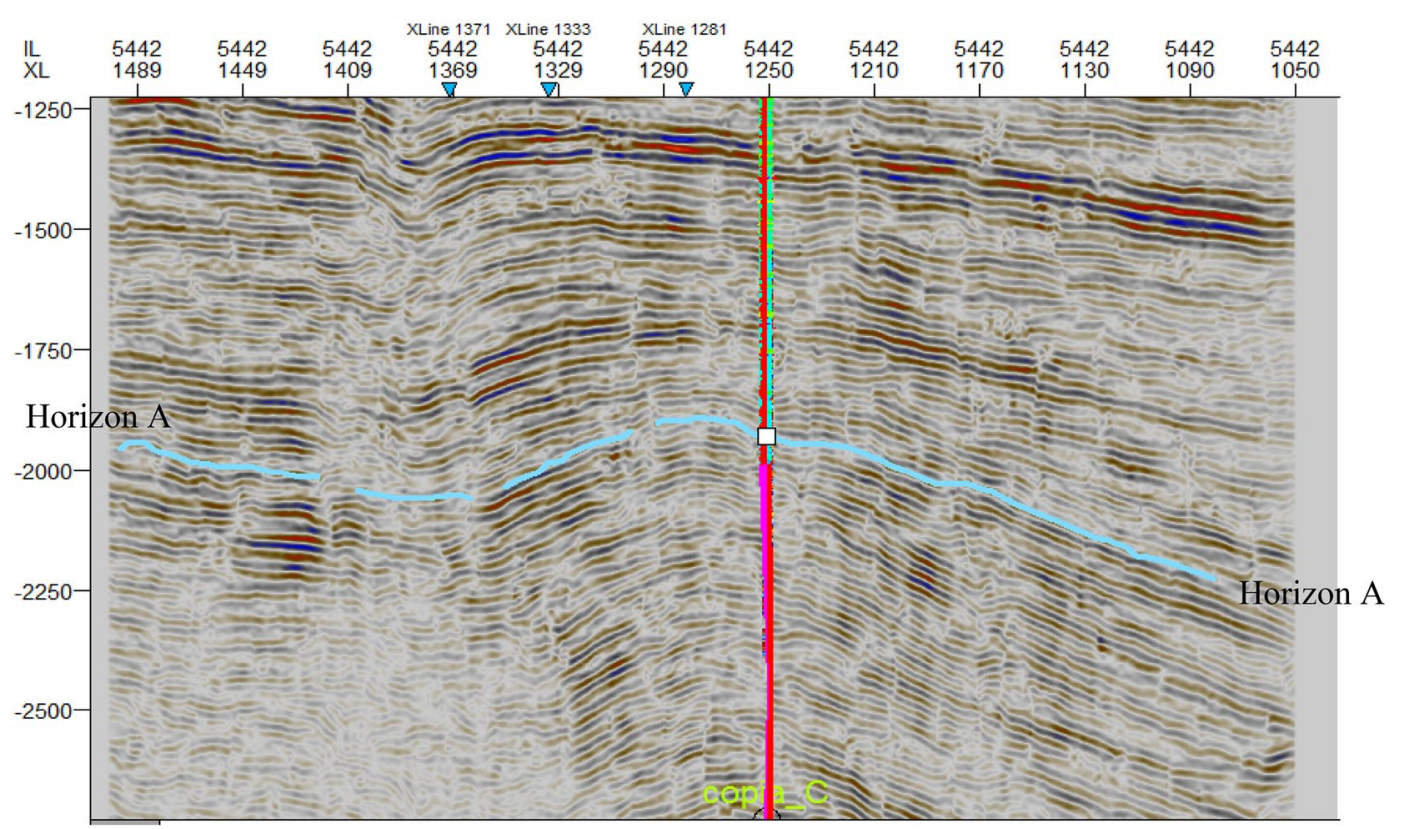

Fig. 7 Inline 5442 showing lateral horizon mapping calibrated by synthetic trace

Fig. 8 Inline section showing interpreted faults

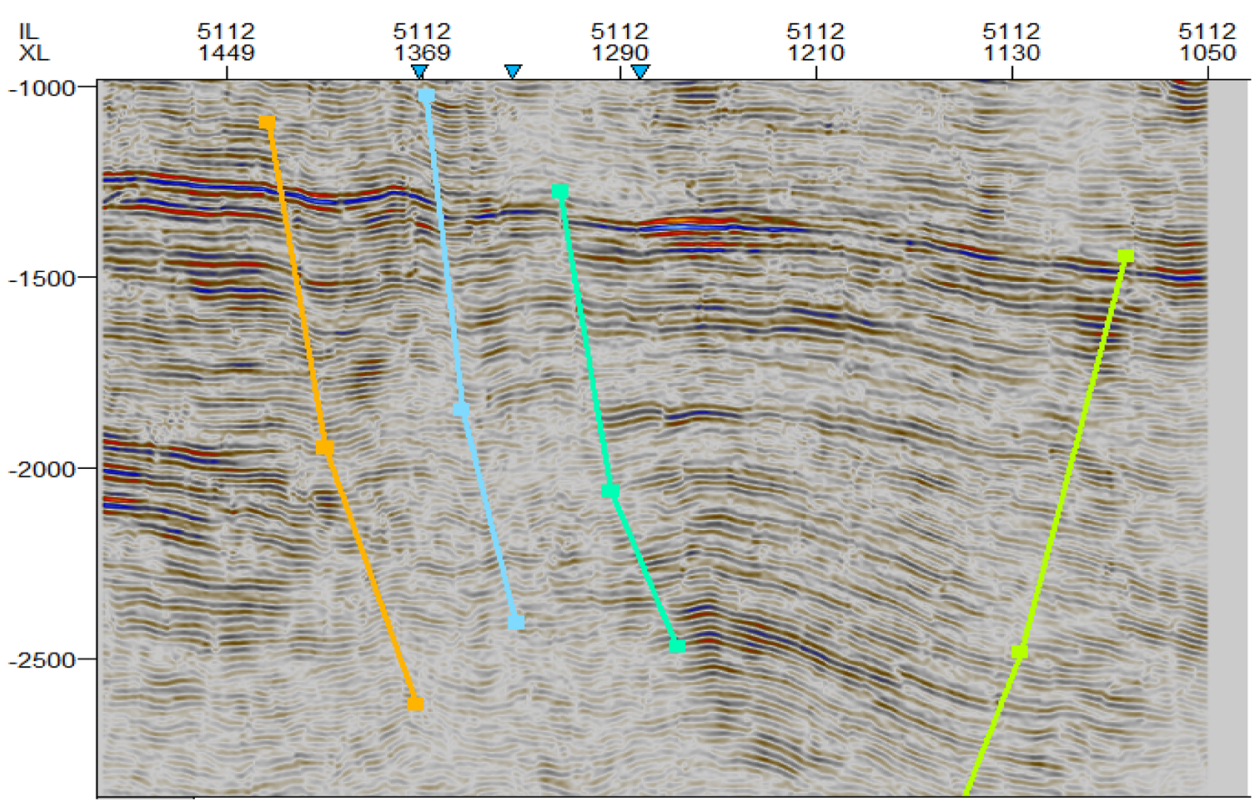

hydrocarbon to be present at wells drilled on the structures the overlying seals are effective and the faults systems are most likely of a sealing nature. However, proper care might be taken when drilling future wells to avoid expulsion of hydrocarbon due to puncturing of fault zones. Anticlinal traps are usually formed due to the mobile diapirism of the lowermost Akata shales in the Niger Delta basin due to its ductile nature (Doust and Omatsola 1990), and are cored by the shales. Sealing faults results from high shale or clay to sand ratio in the fault zones. The presence of impermeable materials within these zones prevents tertiary migration of hydrocarbon and hence prevention of expulsion or loss of reservoir fluids (Sroor 2010).

\section{Seismic attributes analysis}

Amplitude extraction from the seismic data including RMS amplitude and maximum amplitude was carried out for the reservoir sand interval (Figs. 12, 13). This was done to predict variation in lithofacies across the sandstone body since 
Fig. 9 3D view of mapped horizon and interpreted faults
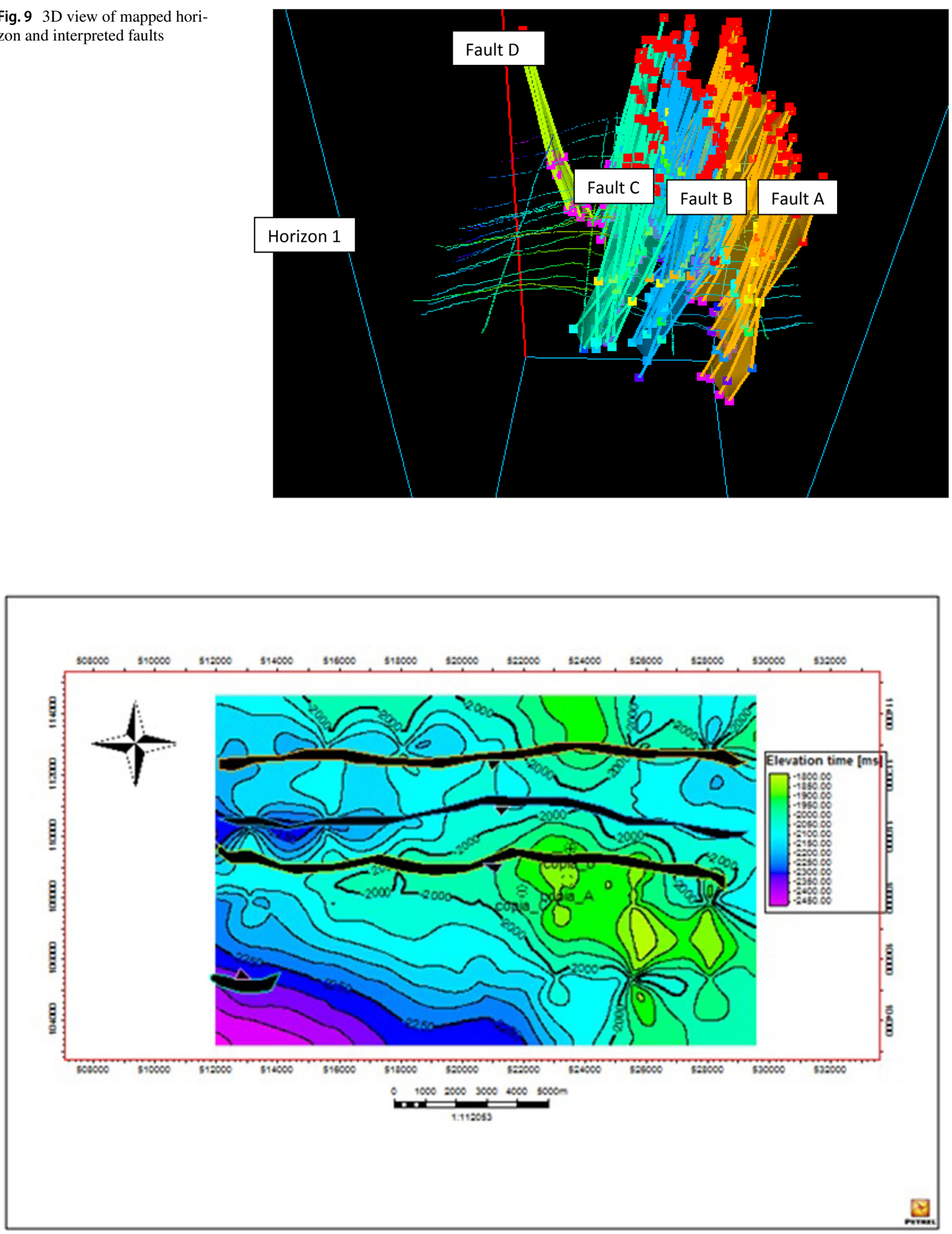

Fig. 10 Time structural map of reservoir 


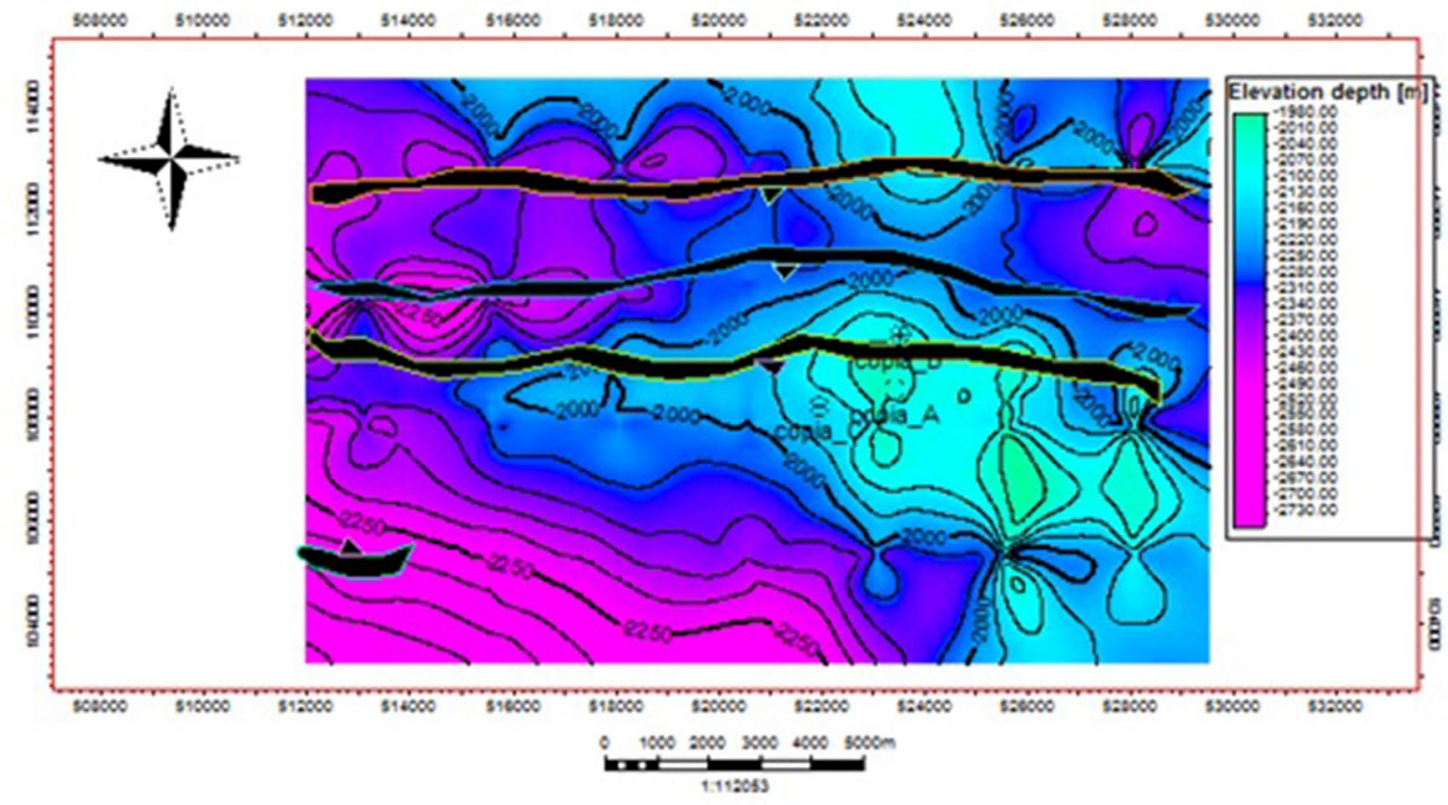

Fig. 11 Depth structural map of reservoir

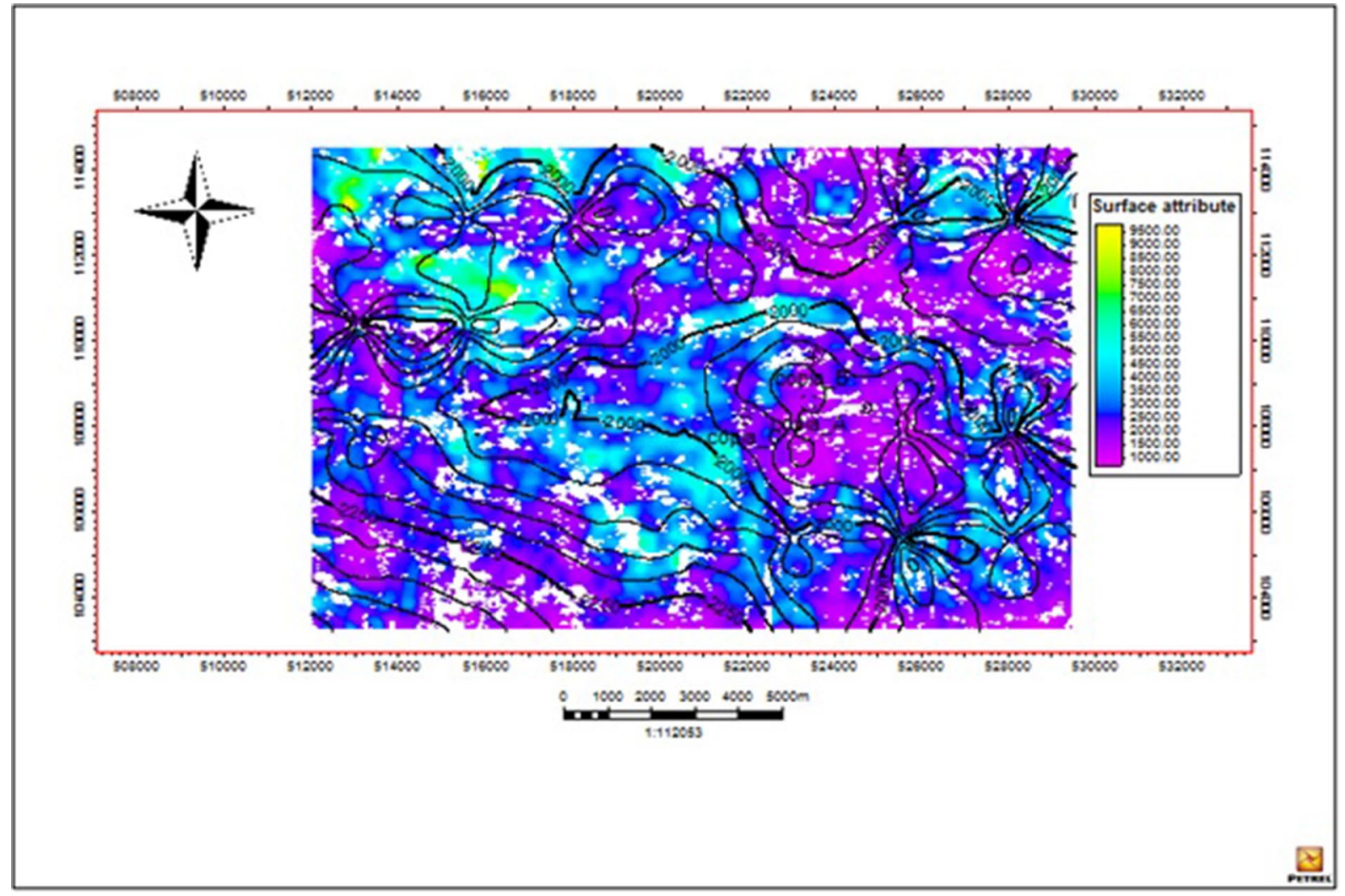

Fig. 12 RMS attribute extracted from reservoir top 


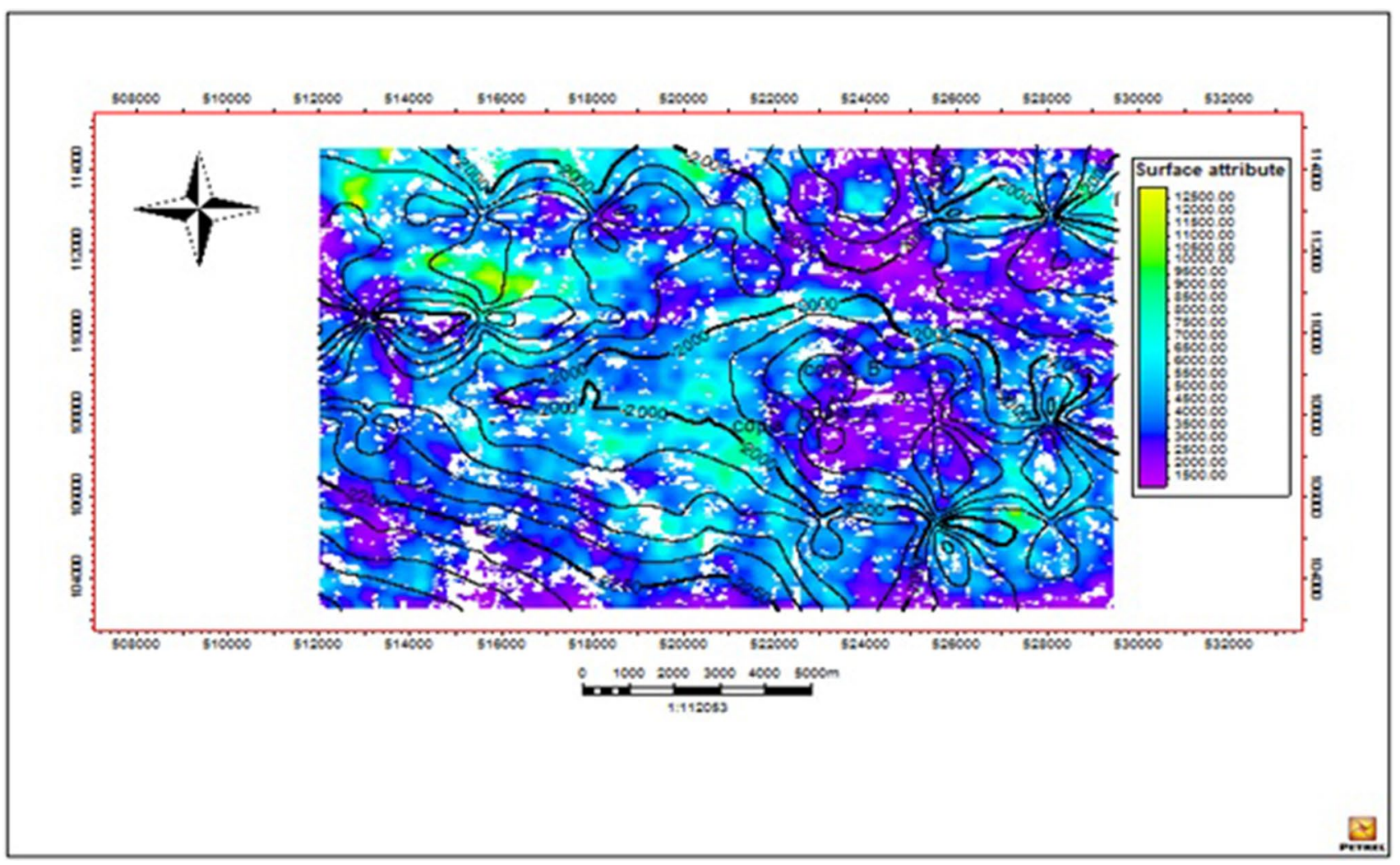

Fig. 13 Maximum amplitude attribute extracted from reservoir top

amplitude pockets correlate with lithofacies variation, as high amplitude corresponds to sandy facies while reduced amplitude indicates clay contents (Catuneanu 2006), and also to calibrate the petrophysical models since amplitude also relates to porosity variation. The drilled wells overlie low-amplitude zones. This is possibly because the pay sandstone zone is too thin to be resolved by the seismic data. There are generally more pockets of low amplitudes across the sandstone body. This might be due to increased shale contents or relatively high volume of shales across the reservoir. In general, when related to structural control, most of the extracted amplitudes at the reservoir level do not conform to structure and hydrocarbon presence (i.e., direct hydrocarbon indicator, DHI); hence, they are more related to lithofacies variation in this case (Alistair 2011).

\section{Conclusion}

Through seismic analysis and well log correlation across the G-field, a hydrocarbon-bearing sandstone reservoir was delineated. The well log suites of gamma and deep resistivity logs aided the delineation and correlation of the sandstone reservoir, while the top was tied to the seismic using synthetic seismogram to determine seismic characters. The quality of the reservoir was determined from petrophysical averages (porosity, water saturation, volume of shale and net to gross). Four listric normal faults were mapped across the field, and the structural trapping mechanism favouring hydrocarbon accumulation in the reservoir is an associated fault-assisted anticlinal structure. Additional hydrocarbon potentials were delineated across the mapped sandstone unit. The extracted amplitude attributes across the reservoir conform more to the lithofacies variation than to the structure (DHI).

Acknowledgements The authors appreciate the funding support of Covenant University and off course, to Shell Petroleum Development Company for releasing the data with which the research was carried out.

Open Access This article is distributed under the terms of the Creative Commons Attribution 4.0 International License (http://creativeco mmons.org/licenses/by/4.0/), which permits unrestricted use, distribution, and reproduction in any medium, provided you give appropriate credit to the original author(s) and the source, provide a link to the Creative Commons license, and indicate if changes were made.

\section{References}

Adejobi AR, Olayinka AI (1997) Stratigraphy and hydrocarbon potential of the Opuama channel complex area, Western Niger Delta. Niger Assoc Pet Explor NAPE Bull 12:1-10 
Alistair RB (2011) Interpretation of 3D seismic data. AAPG Mem 42:294-298

Ameloko AA, Owoseni AM (2015) Hydrocarbon reservoir evaluation of X-field, Niger Delta using seismic and petrophysical data. Int J Innov Sci Res 15(1):193-201

Ameloko AA, Rotimi OJ, Alfa BE, Obihan KI (2016) Reservoir characterization and structural interpretation for prospect evaluation-a case study. Pet Coal 58(2):185-193

Avbovbo AA (1978) Tertiary lithostratigraphy of Niger Delta. Bull Am Assoc Pet Geol 62:297-306

Burke K (1972) Longshore drift, submarine canyons, and submarine fans in development of Niger Delta. American Association of Petroleum Geologists, Tulsa

Catuneanu O (2006) Principles of sequence stratigraphy. Elsevier (p, Amsterdam, p 387

Coffen JA (1984) Interpreting seismic data, vol 2. Penwel Publishing Company, Oklahoma, pp 39-118

Doust H, Omatsola ME (1990) Niger Delta. In: Edwards JD, Santogrossi PA (eds) Divergent/passive margin basin. American Association of Petroleum Geologists, Tulsa, pp 239-248

Evamy BD, Haremboure J, Kamerling P, Knaap WA, Malloy FA, Rowlands PH (1978) Hydrocarbon habitat of Tertiary Niger Delta. AAPG Bull 62:1-39
Lake LW, Carroll HB Jr (1986) Reservoir characterization. Academic Press Inc., Orlando

Short KC, Stauble AJ (1967) Outline of geology of Niger Delta. Am Asso Petrol Geol Bull 51:761-779

Sroor M (2010) Geology and geophysics in oil exploration. Wiley, Hoboken, p 135

Tuttle MLW, Charpentier RR, Brownfield ME (1990) Tertiary Niger Delta (Akata-Agbada) Petroleum System (No. 701901), Niger Delta Province, Nigeria, Cameroon, and Equatorial Guinea, Africa. In: USGS (ed) The Niger Delta Petroleum System: Niger Delta Province, Nigeria, Cameroon, and Equatorial Guinea, Africa. Department of the Interioru, U.S. Geological Survey, Denver

Weber KJ, Daukoru EM (1975) Petroleum geology of the Niger Delta. In: Proceedings of the 9th world petroleum congress. Geology, vol 2. Applied Science Publishers, Ltd., London, pp 210-221

Whiteman A (1982) Nigeria-its petroleum geology, resources and potential, vol 3. Graham and Trotman, London, p 3

Publisher's Note Springer Nature remains neutral with regard to jurisdictional claims in published maps and institutional affiliations. 